PhD Student at the English Philology

and Translation Department

of Borys Grinchenko Kyiv University

y.tsys@kubg.edu.ua

\title{
SCHEMA-ORIENTED LANGUAGE AS A LINGUISTIC INDICATOR OF PERSPECTIVE IN DRAMA
}

Introduction. In modern linguistics the notion of perspective is of high importance when analyzing dramatic texts. Perspective is one of the most significant issues in character construction in plays as it allows a reader to perceive a character comprehensively.

While analyzing perspective in drama it is essential to bear in mind that dramatic texts differ considerably from narrative texts. It is worth specifying that drama is a Greek word "dran" that means an "action". Drama as a kind of literature has a lot of definitions, and in what follows we suggest several that cover its basic features.

Thus, Aristotle in his Poetics defines drama, as "an imitation of an action that is serious, complete, and of a certain magnitude; in language embellished with each kind of artistic ornament, the several kinds being found in separate parts of the play; in the form of action, not of narrative; through pity and fear effecting the proper purgation of these emotions" [1, p. 1077].

For J. Dryden, drama "is a just and lively image of human nature, representing its passions and humours and the changes of fortune to which it is subject for the delight and instruction of mankind" [5, p. 225].

In his turn, M. Esslin in Anatomy of Drama holds that drama is "a mimetic action, action in imitation, or representation of human behavior" [6, p. 14].

All the three scholars claim that the basic feature of drama is imitation of an action, so it is rather about showing, and not retelling an action.

M. Flundernik emphasizes that diegesis or telling as a projection of fictional world as well as mimesis or showing are inherent parts of all genres that tell a story, including drama, but the implementation of them is different [8, p. 29]. In narrative texts mimesis relies on the medium of language, while in drama mimesis is achieved through the re-enactment of the plot, in which the visual presentation dominates.

M. Pfister claims, that "dramatic texts are consistently restricted to the representative mode, so the poet never allowing himself speaking directly" [11, p. 3]. Thus, the receiver of a dramatic text feels directly confronted with the characters represented. In narrative texts, on the contrary, they are mediated by more or less concrete narrator figure.

So, the main aim of why a dramatic text was written is to be transformed into the visual representation. The narrator level as far as almost all narrative elements are absent in plays; consequently, that is one of the reasons why dramatic texts are rarely considered in terms of perspective.

D. McIntyre specifies that despite the fact that the main feature of drama is visual representation, it is the language of a dramatic text that allows the reader to shape the image of its performance [9, p. 141]. M. Short points out that visual presentation of drama is only a derivation from original dramatic text, so to understand how it should be performed and come to a reasonable interpretation of the text the reader needs to analyze the language of the dramatic text [15, p. 139].

Perspective in dramatic texts is hidden in the lines of characters and the author's remarks. In this light, analysis of perspective in dramatic texts lets the reader conceive how the characters relate and characterize each other and events around them.

Perspective in drama in the light of schema theory

Perspective in linguistics is often referred to as a point of view (D. McIntyre) [9], focalization (G. Genette) [2], stance (D. Biber, E. Finegar) [4], appraisal (J.R. Martin) [10] and evaluation (G. Thompson, S. Hunston) [18]. For the purpose of our research, we will use the term "perspective", implying by it an author's or a character's attitude, feelings and evaluation of a certain phenomenon or a character.

According to M. Short, perspective in the text has certain linguistic indicators. They are schema-oriented language, value-laden expressions, given versus new information, thought presentation, character perception, deictic expressions, social deixis, sequencing of actions and events and ideological viewpoint [16, p. 265].

In this paper we limit ourselves to the analysis of schema-oriented language in dramatic texts. Originally, schema theory traces to F. Barlett, who defines schema as an "organized setting" or functional properties of adaptations between persons and their physical and social environments [3, p. 202].

D. Rumelhart states that people's common knowledge is organized in schemata. He holds that "schemata can represent knowledge at all levels-from ideologies and cultural truths to knowledge about the meaning of a particular word, to knowledge about what patterns of excitations are associated with what letters of the alphabet [13, p. 40]. Thus, schemata represent all levels of our experience, at all levels of abstraction.

M. Eysenck and M. Keane determine schema as "a structured cluster of concepts that involves generic knowledge and may be used to represent events, precepts, situations, relations, and even objects [7, p. 275]. In his turn, W. van Peer claims that a writer portrays a character systematically according to a particular schema in order to create a particular schema, such as "femme fatal", "saint", "hero", "underdog" and many others [19, p. 328].

Overall, schema is schematic knowledge about a certain person, situation or event, and schema-oriented language is language that relates to a particular schema. We believe that schema-oriented language is one of the linguistic indicators of perspective in B. Show's Pygmalion [14]. The following examples from the play demonstrate Henry Higgins's perspective concerning his student Eliza Doolitle. In the text of the play they are identified as HIGGINS and LIZA. The character of Higgins is known for his genious skills as a teacher of phonetics and unfavorableness for female gender, so 
he is quite brutal in his remarks addressed to Liza. In relation to Liza, Higgins uses language that is associated with a THING schema, for instance:

"HIGGINS. Pickering: shall we ask this baggage to sit down or shall we throw her out of the window?" [14].

"HIGGINS Put her in the dustbin." [14].

"HIGGINS. Take her away and clean her, Mrs Pearce. Monkey Brand, if it won't come off any other way. Is there a good fire in the kitchen?" [14]

"HIGGINS. Wrap her up in brown paper til they come." [14].

"HIGGINS. Very well, then, what on earth is all this fuss about? The girl doesn't belong to anybody - is no use to anybody but me." [14].

Higgins uses such verbs as throw out, put, take away, clean, wrap up, and belong metaphorically to show that Liza for him is even not a human being, but an inanimate object. These verbs demonstrate that Higgins highly disrespects Liza. By metaphorical use of verbs throw out and put Higgins equals Liza with trash or useless rummage. Higgins tells Mrs Pearce to take Liza away and clean to stress that he hates to be around Liza as if she were a disgusting dirty piece of cloth or an old junk. Belong is used by Higgins in the sense of Liza being his property. The verb wrap up is used by Higgins after Liza was cleaned, so the connotation is a bit different: for him she is a sort of a gift now, but still an item.

In the following two examples Higgins's attitude towards Liza is shown from his mother's perspective:

"MRS HIGGINS. You can't take a girl up like that as if you were picking up a pebble on the beach." [14].

"MRS. HIGGINS. You certainly are a pretty pair of babies, playing with your live doll." [14].

As can be seen from the example, according to Mrs. Higgins her son Higgins treats Liza as a thing. Mrs. Higgins uses a metaphor a pebble on the beach, comparing Liza with a small stone that is usually used to be thrown into the sea or river and watched how it jumps on the water to finally drown just for fun. So, Mrs. Higgins states that for Higgins Liza is just a trinket or a bauble. Another metaphor that is used by Mrs. Higgins in relation to Liza is live doll. She calls her so because Higgins literally plays with Liza's life; he is like a puppeteer and she is like his puppet as he decides everything for her: how to speak, eat, behave and even what to wear. Such comparisons of Mrs. Higgins demonstrate that she does not support her son's way of treating Liza and condemns his behavior.

Higgins's attitude to Lisa changes as their relations evolve. The following examples demonstrate how Higgins's perspective concerning Liza when he just has met her:

"THE NOTE TAKER. Remember that you are a human being with a soul and the divine gift of articulate speech: that your native language is the language of Shakespeare and Milton and The Bible; and don't sit there crooning like a bilious pigeon." [14].

"HIGGINS. What is life but a series of inspired follies? I shall make a duchess of this draggletailed guttersnipe." [14].

The note taker, Higgins is called so in the beginning of the play, Higgins uses a simile crooning like a bilious pigeon when he meets Liza for the first time to stress that Liza's language is incomprehensible, obscure, indistinct and has nothing in common with human language. Higgins is annoyed by her bird language, and he reproaches Liza quite arrogantly. A metaphor draggletailed guttersnipe is used by Higgins to show that Liza's outfit and manners are alike to a homeless child's who has no opportunity to be around people from higher classes. According to Higgins, Liza does not care about her looks and hygiene:

"HIGGINS. YOU won my bet! You! Presumptuous insect! I won it. What did you throw those slippers at me for?" [14].

"HIGGINS [looking at her in cool wonder]. The creature IS nervous, after all." [14].

"HIGGINS. I tell you I have created this thing out of the squashed cabbage leaves of Covent Garden; and now she pretends to play the fine lady with me." [14].

The schema NOBODY as a characterization of Liza is represented with the help of metaphors presumptuous insect, the creature and squashed cabbage leaves of Covent Garden. By calling Liza presumptuous insect Higgins shows that LIZA is too small in his eyes and does not deserve to be heard. In this case Higgins acts as her master who is not delighted with her behavior. The creature that stands for Liza is her likening to a pet, and Higgins here is like her cruel owner who is amused by watching her being anxious. Using a metaphor squashed cabbage leaves of Covent Garden Higgins intensifies association of Liza with NOBODY schema. As far as words an insect and a cabbage can be used in the meaning of a useless and unimportant person, such metaphors express Higgins's contemptuous attitude towards Liza. By specifying that Liza is squashed cabbage leaves Higgins points out Liza's weakness of spirit and her ugly repulsive appearance.

There is one more schema that appears in the text of the play in relation to Liza - BURDAIN schema:

"HIGGINS. Pickering: shall we ask this baggage to sit down or shall we throw her out of the window?" [14].

"HIGGINS. I find that the moment I let a woman make friends with me, she becomes jealous, exacting, suspicious, and a damned nuisance." [14].

"HIGGINS. Of course I do, you little fool. Five minutes ago you were like a millstone round my neck." [14].

The metaphor this baggage [14] is used by Higgins to imply that Liza for him is a heavy load as if he was burdened to carry her on his shoulders. By metaphorically calling Liza a damned nuisance [14] Higgins associates her with an obstacle or a barrier on his way to ideal relationships and his own harmony. Higgins uses a simile like a millstone round my neck [14] to demonstrate that he supports Liza's life and personal growth in all senses as if she sat on his head with her legs dangling and Higgins were very tired of it. So, metaphorically Liza is heavy enough for him to bear.

The next example presents the POWER schema, applicable to Liza in the end of the play:

"HIGGINS. Now you're a tower of strength: a consort battleship." [14].

A metaphor a tower of strength in reference to Liza is applied by Higgins to mark Liza's appeared inner force and solidity. For him Liza now is an adamantine and a reliable person. By using a metaphor a consort battleship towards his student Higgins stresses that she is ready to struggle for her rights to the bitter end. Higgins sees that Liza would literally declare a war if someone tries to cross her path because she emits self-confidence and full alertness.

Finally, the PIECE OF ART schema that concerns Liza from Higgins's perspective is demonstrated in the following examples:

"HIGGINS. They might as well be blocks of wood" [14].

"HIGGINS. I'm not going to have my masterpiece thrown away on Freddy." [14] 
Higgins calls his students, including Liza, to be blocks of wood contrasting her with a trunk of a tree that would soon turn into a wooden sculpture in the hands of a talented wood engraver, or a blank canvas that would soon be a painting thanks to a gifted artist's brush. Therefore Liza is seen by Higgins as a clear sheet of paper. Thus Higgins thinks that Liza knows nothing about articulating sounds, behavior in public, neatness and tidiness, and he is going to change it. By applying a metaphor my masterpiece towards Liza he highlights that she is an ideal in sense of phonetics, manners and appearance. Moreover Higgins is known to be a narcissistic, presumptuous and self-confident person, so he considers himself to be the creator of this piece of art.

Conclusions and discussion.

Overall, Higgins's perspective concerning Liza has changed throughout the text of the play from treating her as "a useless thing" to acknowledging her to be "a beautiful masterpiece". So, schemata that were implied by the author in reference to Liza were changing together with the development of her character. The gradual change of schemata allowed the reader to see Liza's inner and outer changes from Higgins's perspective.

At the same time, this might had an effect on the reader's perspective towards Liza. In the beginning of the play, the reader perceives Liza as a simple silly girl and even feels sorry for her as a result of Higgins's attitude towards her. But in the end of the play the reader sees her as an intelligent lady who is confident in her strengths; consequently, a reader feels proud of Liza. In our view, this results from transformation of one schema into another one. Firstly, Liza was associated with a THING and the reader subconsciously underestimates Liza. But then the PIECE OF ART schema came into action, and the reader subconsciously started to admire Liza.

Thus, the use of linguostylistic devices is important in construction of schema and building the image of Liza itself. As metaphors and similes are built on association of comparison, they allow the reader to let his/her imagination out and build up a colorful and vivid image of a character.

To sum up, schema-oriented language represents a certain schema in the text of drama that helps a reader to shape his/ her expectations towards the development of a character.

For the future research, it seems reasonable to verify the reader's reaction to the schema change in the play by way of an experiment, conducted in line with the tenets of empirical approach in the Humanities [5]. This could cast light on the reader's sensitivity to the schematic evolution outlined in the article.

\section{Література:}

1. Аристотель. Этика. Политика. Риторика. Поэтика. Категории. / пер. С. Жебелев, Н. Платонова, Э. Радлов, А. Кубицкий, Н. Новосадский. Москва : Литература, 1998. 1392 с.

2. Женетт Ж. Фигуры : в 2 т. Москва : Изд-во им. Сабашниковых, 1998. Т. 2. 472 с.

3. Barlett F. Remembering: A Study in Experimental and Social Psychology. Cambridge : Cambridge University Press, 1995. 344 p.

4. Biber D., Finegan E. Adverbial Stance Types in English. Discourse Processes. 1988. № 11. P. 1-34.

5. Directions in Empirical Literary Studies: In honor of Willie van Peer / ed. by S. Zyngier, M. Bortolussi, A. Chesnokova, J. Auracher. Amsterdam, Philadelphia : John Benjamins, 2008. 360 p. DOI: 10.1075/lal.5 (access date: 02.02.2019).

6. Esslin M. Anatomy of Drama. New York : Hill and Wang, 1977. 125 p.

7. Eysenk M. Cognitive Psychology: A Student's Handbook / M. Eysenk, M. Keane. London : Psychology Press, 2010. $856 \mathrm{p}$.

8. Flundernik M. The Fictions of Language and the Languages of Fiction. London : Routledge, 2003. $556 \mathrm{p}$.

9. McIntyre D. Point of View in Drama: A Socio-Pragmatic Analysis of Dennis Potter's Brimstone and Treacle. Language and Literature. 2004. № 13. P. 139-160. URL: http://lal.sagepub.com/content/13/2/139 (access date: 02.02.2019).

10. Martin J.R. Beyond Exchange: APPRAISAL Systems in English. Evaluation in Text: Authorial Stance and the Construction of Discourse / ed. by S. Hunston, G. Thompson. Oxford : Oxford University Press, 2000. P. 142-175.

11. New Perspectives on Narrative Perspective / ed. by W. van Peer, S. Chatman. Albany : SUNY Press, 2001. 412 p.

12. Pfister M. Theory and analysis of Drama / trans. by J. Halliday. New York : Cambridge University Press, 1993.337 p.

13. Prince G.J. Narratology: The form and functioning of narrative. New York : Mouton de Gruyter, 1982. 191 p.

14. Rumelhart D. Schemata: The Building Blocks of Cognition. Theoretical Issues in Reading Comprehension / ed. By R. Spiro, B. Bruce, W. Brewer. Mahway : Erlbaum Associates, 1980. P. 33-58.

15. Shaw B. Pygmalion. URL: http://www.gutenberg.org/files/3825/3825-h/3825-h.htm (access date: 02.02.2019).

16. Short M. Discourse Analysis and the Analysis of Drama. Language, Discourse and Literature / ed. by R. Carter and P. Simpson. London Unwin Hyman, 1989. P. 137-168.

17. Short M. Exploring the Language of Poems, Plays, and Prose. London : Longman, 1996. 416 p.

18. The Works of John Dryden. Verse and Prose, With a Life / ed. by G. Saintsbury. London : Forgotten Books, 2018. P. 468.

19. Thompson G., Hunston S. Evaluation: An Introduction. Evaluation in Text: Authorial Stance and the Construction of Discourse / ed. by S. Hunston, G. Thompson. Oxford : Oxford University Press, 2000. P. 1-26.

\section{References:}

1. Aristotel (1998). Etika. Politika. Ritorika. Poetika. Katehorii. [Ethics. Politics. Rhetoric. Poetics. Categories] / tr. S. Jebelev, N. Platonova, Ye. Radlov, A. Kubitskiy, N. Novosadsky. Moscow : Literatura, 1392 [in Russian].

2. Jenett J. (1998). Fihury: v 2 t [Figures: in 2 v]. Moscow : Izd-vo im. Sabashnikovykh, 1998, 2 , 472 [in Russian].

3. Barlett F. (1995). Remembering: A Study in Experimental and Social Psychology. Cambridge : Cambridge University Press, 344.

4. Biber D., Finegan E. (1988). Adverbial Stance Types in English. Discourse Processes. 1988, 11, 1 - 34.

5. Directions in Empirical Literary Studies: In honor of Willie van Peer (2008) / ed. by S. Zyngier, M. Bortolussi, A. Chesnokova, J. Auracher. Amsterdam, Philadelphia : John Benjamins, 360. DOI: 10.1075/lal.5.

6. Esslin M. (1977). Anatomy of Drama. New York : Hill and Wang, 125.

7. Eysenk M. (2010). Cognitive Psychology: A Student’s Handbook / M. Eysenk, M. Keane. London : Psychology Press, 856.

8. Flundernik M. (2003). The Fictions of Language and the Languages of Fiction. London : Routledge, 556. 
9. McIntyre D. (2004). Point of View in Drama: A Socio-Pragmatic Analysis of Dennis Potter's Brimstone and Treacle. Language and Literature. 13, 139 - 160. Retrieved from: http://al.sagepub.com/content/13/2/139.

10. Martin J.R. (2000). Beyond Exchange: APPRAISAL Systems in English. Evaluation in Text: Authorial Stance and the Construction of Discourse / ed. by S. Hunston, G. Thompson. Oxford : Oxford University Press, $142-175$.

11. New Perspectives on Narrative Perspective (2001) / ed. by W. van Peer, S. Chatman. Albany : SUNY Press, 412.

12. Pfister M. (1993). Theory and analysis of Drama/trans. by J. Halliday. New York : Cambridge University Press, 337.

13. Prince G.J. (1982). Narratology: The form and functioning of narrative. New York : Mouton de Gruyter, 191.

14. Rumelhart D. (1980). Schemata: The Building Blocks of Cognition. Theoretical Issues in Reading Comprehension / ed. By R. Spiro, B. Bruce, W. Brewer. Mahway : Erlbaum Associates, 33 - 58.

15. Shaw B. Pygmalion. Retrieved from: http://www.gutenberg.org/files/3825/3825-h/3825-h.htm.

16. Short M. (1989). Discourse Analysis and the Analysis of Drama. Language, Discourse and Literature / ed. by R. Carter and P. Simpson. London Unwin Hyman, 137 - 168.

17. Short M. (1996). Exploring the Language of Poems, Plays, and Prose. London : Longman, 416.

18. The Works of John Dryden. Verse and Prose, With a Life (2018) / ed. by G. Saintsbury. London : Forgotten Books, 468.

19. Thompson G., Hunston S. (2000). Evaluation: An Introduction. Evaluation in Text: Authorial Stance and the Construction of Discourse / ed. by S. Hunston, G. Thompson. Oxford : Oxford University Press, $1-26$.

\section{Summary \\ J. TSYS. SCHEMA-ORIENTED LANGUAGE AS A LINGUISTIC INDICATOR OF PERSPECTIVE IN DRAMA}

The article attempts at analysis of schema-oriented language as a linguistic indicator of perspective in B. Show's Pygmalion. The author looks at linguostylistic devices that are used to implement schema-oriented language in the play as they construct the perspective. The linguostylistic analysis of perspective in B. Show's Pygmalion lends support to the idea that the main stylistic means of expressing schema-oriented language in this text is metaphor.

Key words: drama, play, perspective, point of view, schema, schema-oriented language, linguistic indicators of perspective, linguostylistic means.

\section{Анотація \\ Ю. ЦИС. СХЕМАТО-ОРІЕНТОВАНА МОВА \\ ЯК ЛІНГВІСТИЧНИЙ МАРКЕР ПЕРСПЕКТИВИ У ДРАМІ}

У статті досліджено схемато-орієнтовану мову як лінгвістичний маркер перспективи у драмі на матеріалі п’єси Б. Шоу «Пігмаліон».

Драма як рід літератури є обмеженою у способах вираження перспективи через відсутність експліцитного наратора. У зв'язку з цим зроблено пошук способів реалізації перспективи саме у драматичному тексті. Перспектива у драматичному тексті може бути вираженою у пролозі, епілозі, авторських ремарках, діалогах персонажів, піснях хору, вбудованих наративах та репліках епічних героїв. У перспективі в тексті драми $є$ лінгвістичні індикатори, одним із найпоширеніших вважаємо схемато-орієнтовану мову. Схемати є ментальними структурами, що відображають різні аспекти світу і використовується для організації знань. Схемато-орієнтована мова $є$ мовою, що стосується певної схеми. У творі письменник навмисно може зображати персонажа відповідно до певної схеми. Схемато-орієнтована дає змогу читачеві, зокрема, зрозуміти авторську і персонажну перспективи у тексті та сформувати власну перспективу щодо персонажу або подій. Так, у п’єсі Б. Шоу «Пігмаліон» драматург використав схемато-орієнтовану мову для формування перспективи Генрі Хіггінса, що характеризує образ його студентки Елізи Дулітл. Отже, перспектива Генрі Хіггінса щодо Елізи Дулітл була представлена такими схемами, як «РІЧ», «НІХТО», «ТЯГАР», «СИЛА», «ВИТВІР МИСТЕЦТВА», сформовані за допомогою метафор, що дало змогу читачеві сформувати власну перспективу щодо образу Елізи Дулітл та інтерпретувати ії образ відповідно до власних схем. Також було встановлено, що перспектива Генрі Хіггінса, що характеризує Елізу Дулітл, поступово змінювалась, що підтверджено зміною схем, що ії характеризують. У результаті лінгвостилістичного аналізу засобів на позначення перспективи встановлено, що метафора є найпоширенішим стилістичним засобом, що використовується у схемато-орієнтованій мові задля вираження перспективи. Таким чином, передбачуваність схеми та ії дешифровка робить читача зацікавленим у інтерпретації образу персонажа.

Ключові слова: драма, п’єса, перспектива, точка зору, схемата, схемато-орієнтована мова, лінгвістичні маркери перспективи, лінгвостилістичні засоби. 